\title{
System Impressed Current Anti Fouling (ICAF) Against Micro Fouling (Bacteria) on Ship's Cooling System
}

\author{
Herman Pratikno ${ }^{1, *}$, Harmin Sulistiyaning Titah ${ }^{2}$, and Muhammad Danesto Rizky \\ Mauludin ${ }^{1}$ \\ ${ }^{1}$ Departement of Ocean Engineering, Faculty of Marine Technology, Institut Teknologi Sepuluh \\ Nopember, Keputih, Sukolilo, 60111 Surabaya, Indonesia \\ ${ }^{2}$ Departement of Environmental Engineering, Faculty of Civil, Environmental and Geo Engineering, \\ Institut Teknologi Sepuluh Nopember, Keputih, Sukolilo, 60111 Surabaya, Indonesia
}

\begin{abstract}
Bio-fouling is the attachment and accumulation of an organism or micro-organism to a material. Bio-fouling is one of the causes of declining performance and quality in a system of structures, especially structures that have a direct relationship with the waters where the biofouling live and move. The research was conducting using a simple circuit that represents Impressed Current Anti Fouling (ICAF) system which is generally located on the cooling of the ship against micro-fouling or bacteria. Species of bacteria (Pseudomonas fluorescens) in the marine environment was used as an object. The bacteria were introduced into the reactor containing the cathode and anode of this simple system, with inputs of experimental time variation of 3,5 and 7 minutes and electrical current variation of $0.1,0.3$, and 0.5 Ampere. The determination of bacteria population was conducted using standard plate count methods. The results showed that ICAF system can reduce the bacteria populations. The largest percentage of Pseudomonas fluorescens reduction was $99.9 \%$, while the smallest percentage showed $98.5 \%$ percentage. In conclusion, the simple of ICAF system can be used to prevent appearance of micro-fouling in marine environment.
\end{abstract}

\section{Introduction}

The most commonly material in the offshore technology is definitely from metal. Metals have different corrosion resistance. The problem with the oxidation of a metal material lies in almost every element on earth, such as water or air. Corrosion caused by water, especially seawater on an offshore structure is inevitable. The sea water has a rapid corrosion rate, caused by salinity present in seawater or solid and gaseous solutes, such as inorganic salts, dissolved gases and organic compounds of living organisms. Sea water can dissolve other substances in large quantities than other liquids. Therefore, the anti-corrosion system is needed by all structures which directly contact to sea water.

* Corresponding author: hermankelautan@gmail.com 
Corrosion due to algae and bacteria is the most common in the category of biological corrosion. The affects of microorganisms on biocorrosion in the marine environment is more than macroorganisms. The bio-corrosion or microbial influenced corrosion (MIC) occurs due to the fixation of bacteria, release of metabolites and formation of biofilms that induce or accelerate the corrosion process [1].

Bio-fouling that was caused by microorganism or it was called as biofilm is ubiquitous in aquatic environments. Micro-fouling were accumulation of many types of microorganisms such as bacteria, fungi, algae, diatom, protozoa etc.,. Bacteria is the first and predominant type of microorganisms in the marine environment [2]. According to Donlan [3], biofilm is an accumulation of microorganisms that is irreversibly associated with a surface and enclosed in a matrix of primarily polysaccharide material. A single bacterium can form biofilm, but in natural environment biofilms are formed by a wide group of organisms. Moreover, it is becoming clear that these natural assemblages of bacteria within the biofilm matrix function as a cooperative consortium [4].

Many microorganisms can produce polymeric substances outside the body (exudates); these are called as extracellular polymeric substances (EPS). EPS is called by different names, such as slime, mucus, mucilage, glycocalyx and exopolymer [5]. The major component of the EPS is sugars (including neutral sugars, uronic acids and hexosamines).Pseudomonas is one of genus that can produce EPS [6]. Pseudomonas (and other aerobic bacteria) have been shown to both increase and decrease the rate of metal corrosion through polymer production during biofilm formation [7,8]. Pseudomonas sp. 200 was known to accelerate corrosion with increasing growth rate [9]. Pseudomonas sp that isolated from products of corrosion of diesel pipelines and metal surfaces immersed in fresh water and sea water could produce EPS that favors the formation of biofilm [1]. Pseudomonas fluorescens as an example of bacteria in the marine environment of shallow depth (pelagic) which of course as the location where the hull of the ship is located. Pseudomonas fluorescens is one of species of bacteria that can cause the microfouling. Pseudomonas fluorescens SBW25 produced biofilms that were comprised of extensive, extracellular non-periodic webs of fine $(<20 \mathrm{~nm}$ wide) cellulose fibers [10]. According to Baum et al. [11], polysaccharides were found to make up a smaller fraction of the biofilm mass (ca. $15 \% \mathrm{wt}$ ), and were of the magnitude expected in a vegetative bacterial cell. These results are atypical for EPS produced by Pseudomonads, which generally have a higher sugar-protein ratio. However, based on Raza et al. [12], the EPS that produced by a newly isolated strain Pseudomonas fluorescens WR-1 was composed of arabinose, glucose and uronic acid.

Based on our previous study, 3 species of bacteria Escherichia coli, Pseudomonas fluorescens, and Thiobacillus ferroxidans can caused bio-corrosion on steel structures of ASTM A106 and A53 in deep seawater (salinity of 33\%o), medium seawater (salinity of $35 \%$ ), and shallow seawater (salinity of 37\% ) [13] The bio-corrosion rate by $P$. fluorescenson Aluminium Alloy 6063 at salinity of 37\%o increased by one point six-fold compared with the condition without bacteria addition at the same salinity [14].

Sacrificial Anode, Impressed Current Cathodic Protection(ICCP) and Impressed Current Anti Fouling (ICAF) are three ways to avoid or slow down corrosion on a metal. The use of anti-corrosion systems such as ICCP and ICAF should continue to be developed so that a shortage of sacrificial anode system can be decreased. New innovation in it is also urgently needed to improve the effectiveness and efficiency of the corrosion prevention tool. ICAF is short of impressed current anti-fouling. Its function is to prevent or inhibit the growth of fouling, which in this case is caused by marine biota, such as barnacles, shellfish, algae, and other marine plant species. Fouling is very detrimental because it attaches to the hull of the ship so that it can increase the prisoner of the ship. Research on how effective the system is killing a fouling is still limited. The aim of the research was to determine the 
decreasing precentage of population of Pseudomonas fluorescens using simple ICAF system.

\section{Materials and methods}

\subsection{Preparation of ICAF System}

A simple ICAF System was designed based on adoption from ships cooling system. In this system, the DC current was be used due to the supply the anode and cathode must be distinguished between positive and negative current sources. Both the anode and the cathode are various types, depending on the material to be protected and how long it will be used. The metal of Cuprum $(\mathrm{Cu})$ was be used as anode with dimension of $15 \times 15 \times 1 \mathrm{~cm}$ and he material of high-strength low-alloy (HSLA) steel was be used as cathode. Figure 1 showed the ICAF system.

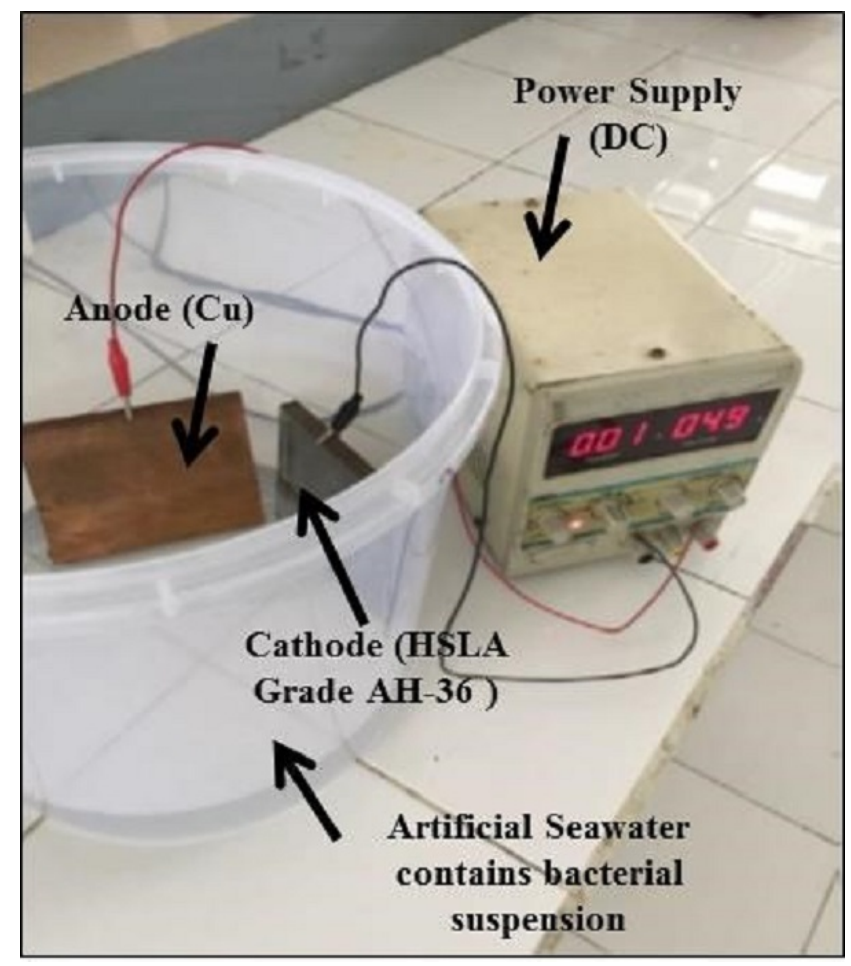

Fig. 1. Simple of ICAF System.

\subsection{Preparation of artificial seawater}

This research used a chemical solution instead of sea water with a salinity of $35 \%$. Salinity of $35 \%$ is the salinity in the ocean of medium depths, where in the microorganism commonly found at this depth, including bacteria. The chemical composition of seawater replacement is in accordance with ASTM D1141-90, 1994 [15].

\subsection{Preparation of Bacteria}


The preparation of bacteria was conducted based on Pratikno and Titah [16]. The pure culture of Pseudomonas fluorescens was be inoculated onto nutrient agar (NA) media using streak plate technique based on Harley and Prescott [17]. The age of bacteria for the test was $24 \mathrm{~h}$. After that, one colony of bacteria was transferred to nutrient borth (NB) and keep in shaker incubator of Innova 2000 (New Brunswick-Eppendorf, Germany) at $150 \mathrm{rpm}$ and room temperature, $33{ }^{\circ} \mathrm{C}$ for $24 \mathrm{~h}$. The cell suspension of selected bacteria was prepared by harvesting the cells at the middle of the logarithmic phase, based on the typical of growth rate graph for the selected bacteria. At this time, the OD at $600 \mathrm{~nm}$ was 1.0 was determined using UV spectrophotometer Genesys 20 (Thermo, USA). The cells were harvested through centrifugation of Jouan E82 (Thermo, USA) at 4,000 rpm for $15 \mathrm{~min}$. The obtained pellet was then washed twice using $8.5 \mathrm{~g} \mathrm{NaCl} / 1000 \mathrm{~mL}$ solution. The suspension of bacteria was ready to be used in ICAF system test.

\subsection{Determination of Bacterial Population}

Colony-forming units (CFU or cfu) is a measure of viable bacterial. CFU measures only viable cells by direct microscopic counts (cell counting using bacterial colony counter or $\mathrm{BBC}$ ). For convenience, the results are given as $\mathrm{CFU} / \mathrm{mL}$ (colony-forming units per milliliter) for liquids, and CFU/g (colony-forming units per gram) for solids. The CFU was conducted using pour-plate technique based on Harley and Prescott [17]. Calculation of the number of bacteria (CFU) per milliliter or gram of sample by dividing the number of colonies by the dilution factor. A wide series of dilutions (e.g., $10^{-4}$ to $10^{-10}$ ) is normally plated because the exact number of live bacteria in the sample is usually unknown. Greater precision is achieved by plating duplicates or triplicates of each dilution. That is, the final plates in the series should have between 25 and 250 colonies. Fewer than 25 colonies are not acceptable for statistical reasons, and more than 250 colonies on a plate are likely to produce colonies too close to each other to be distinguished as distinct CFU. The number of colonies per $\mathrm{ml}$ reported should reflect the precision of the method and should not include more than two significant figures. The CFU/ml can be calculated using the formula:

$$
\mathrm{CFU} / \mathrm{ml}=\frac{\text { no. of colonies } \mathrm{x} \text { dilution factor }}{\text { volume of culture plate }}
$$

\subsection{Running of ICAF System}

Running test of ICAF system were carried out based on the time variation (3, 5 and 7 min) and electrical current $(0.1,0.3$, and 0.5 Ampere). The main parameter was the population of Pseudomonas fluorescens at initial time and after operation of ICAF system. The determination of population of Pseudomonas fluorescens was conducted using pour plate count methode based on Harley and Prescott's standard plate count [17].

\section{Results and Discussion}

Figure 2 showed the results of simple ICAF system running. Based on this graph, reduction of Pseudomonas fluorescens population was higher during the time increased. Hong et al. [18] reported that fluorescently-tagged Pseudomonas aeruginosa bacterial cells were adhered onto a glass slide with a conductive layer of indium tin oxide (ITO). Anodic and cathodic currents of $15 \mathrm{uA} / \mathrm{cm} 2$ were be applied to the ITO layer, and bacterial detachment was monitored with a fluorescent microscope. After 20 minutes of application of the cathodic current, the total number of attached bacteria dropped to $20 \%$. At the $40-$ 
minute, the population on the surface with anodic current fell to approximately $70 \%$. Based on Gabi et al. [19], anodic microcurrents with current densities of $75 \mathrm{nA} / \mathrm{mm} 2$ and 750 $\mathrm{nA} / \mathrm{mm} 2$ were shown to increase the formation of biofilms on the surface of a platinum $(\mathrm{Pt})$ - coated quartz crystal.

The decreasing of Pseudomonas fluorescens population trends were occurred at all variation of electrical current $(0.1,0.3$, and 0.5 Ampere). According to Berthelot [20], the effect of current applied across a substrate's surface has also been shown to affect bacterial attachment. The electrical current of 0.07 and $0.125 \mathrm{~mA}$ reduced the motility of Pseudomonas aeruginosa and Escherichia coli, indicating that there were be an optimal range of current that will predictably and consistently impact to bacterial species.

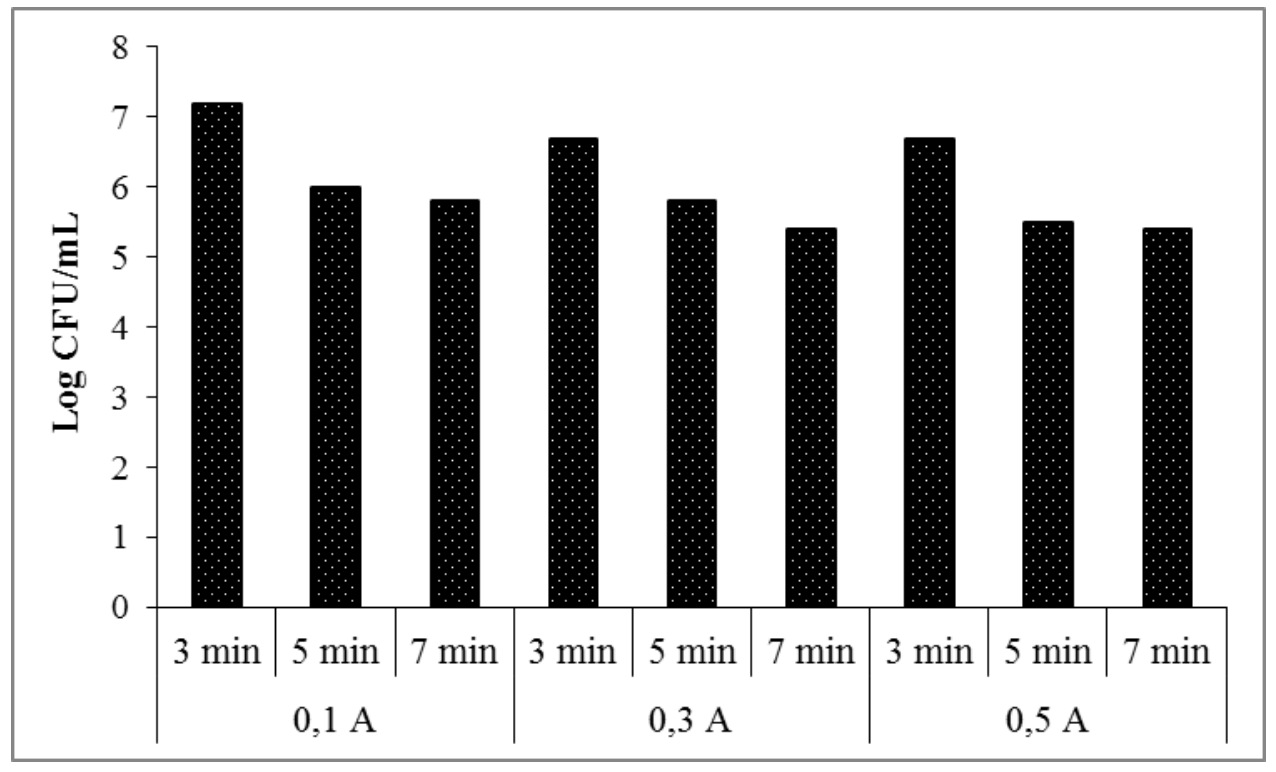

Fig. 2. Population of Pseudomonas fluorescens population at variation of electrical current after 3, 5, $7 \mathrm{~min}$ in ICAF system.

Based on Figure 3, the lowest percentage of Pseudomonas fluorescens population reduction occured at combination of variables with duration time of 3 minutes and electrical current of $0.1(98.5 \%)$, while the largest percentage reached $99.9 \%$ at combination of variables with duration time of 7 minutes and electrical current of $0.5 \mathrm{~A}$. The reason this number is not zero is because although bacteria have a net negative charge, they still have localized regions of positive charge from surface proteins attracting them to the substrate, and chemical substances, such as EPS, helping them stay adhered Berthelot [20]. 


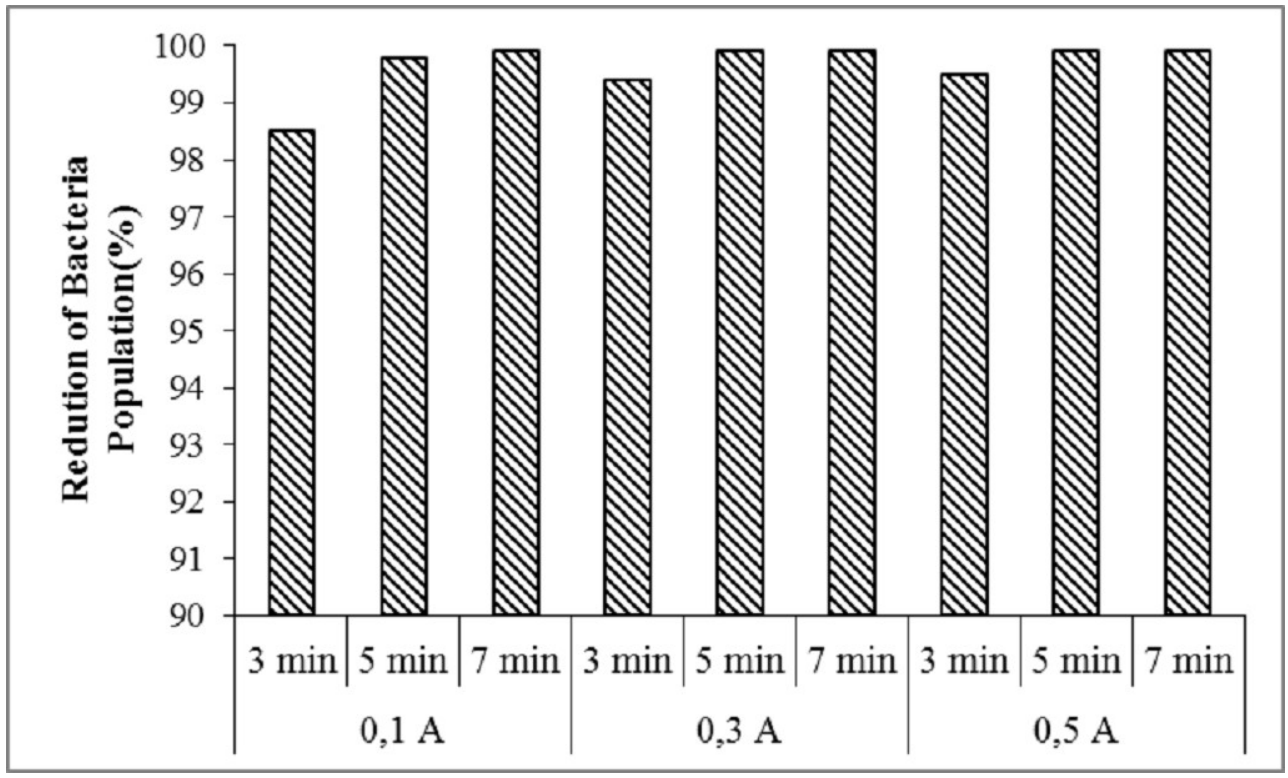

Fig. 3. Reduction Percentage of Pseudomonas fluorescens population.

\section{Conclusion}

The range of reduction of Pseudomonas fluorescens population was $98.5 \%$ to $99.9 \%$, it indicated that the simple of ICAF system can reduce of Pseudomonas fluorescens population. The data will be used for the further investigation.

The author would like to thank KemenristekDIKTI through scheme of Penelitian Dasar Unggulan Perguruan Tinggi - PDUPT 2018 No. 890/PKS/ITS/2018 for funding this research.

\section{References}

1. M.C. Moura, E.V. Pontual, P.M.G. Paiva, L.C.B.B. Coelho. Méndez-Vilas A, Ed. Formatex. 11-22 (2013)

2. B. Marhaeni, O.K. Radjasa, M.M. Khoeri, A. Sabdono, D.G. Bengen, H. Sudoyo. J of Environ Protect 2(9) 1245 (2011) doi: 10.4236/jep.2011.29143.

3. R.M. Donlan. Emerging Infectious Diseases 8(9) 881-890 (2002)

4. M.E. Davey, G.A.O'toole. Microbiolo And Molecular Biol Rev 64(4) 847-867 (2000)

5. G.J.C. Underwood, D.M. Paterson, R.J. Parkes. Limnol and Oceano 40 1243-1253 (1995)

6. N. Muthukumar, A. Rajasekar, S. Ponmariappan, S. Mohanan, S. Maruthamutu, S. Muralidharan, P. Subramanian, N. Palaniswamy, N. Raghavan. Indian J of Experimen Botany 41 1012-1022 (2003)

7. J.P.Black, T.E. Ford, R. Mitchell. Corrosion 88, National Association of Corrosion Engineers, Houston, Texas. (1988)

8. D.E. Nivens, P.D. Nichols, J.M. Henson, G.C. Geesey, D.C. White. Corrosion 42 204$210(1986)$ 
9. C.O. Obuekwe, D.W.S.Westlake, J.A. Plambeck. Canadian J of Microbiol 33 272275 (1987)

10. A.J. Spiers, J. Bohannon, S.M. Gehrig, P.B. Rainey. Molecular Microbiol 50(1) 15-27 (2003)

11. M.M. Baum, A. Kainović, T. O'Keeffe, R. Pandita, K. McDonald, S. Wu, P. Webster. BMC Microbiol 9(103) 1-13 (2009)

12. W. Raza, W. Yang, Y. Jun, F. Shakoor, Q. Huang, Q. Shen. Carbohydr Polym 1;90(2) 921-929 (2012) doi: 10.1016/j.carbpol.2012.06.021

13. H. Pratikno, H.S. Titah. Asian J of Appl Sci 9 120-125 (2016)

14. H. Pratikno, H.S. Titah. Int J of ChemTech Res 9(12) 600-609 (2016)

15. American Society for Testing and Materials. ASTM D1141-98 Standard Practice for Artificial Sea Water ASTM Society (2004)

16. H. Pratikno, H.S. Titah. IPTEK, The J for Technol and Sci 28(2) 55-58 (2017)

17. J.P. Harley, L.M. Prescott. Laboratory exercises in microbiology. Fifth Edition McGraw-Hill Companies Texas. (2002)

18. H.S. Hong, J. Jeong, S. Shim, H. Kang, S. Kwon, K. Ahn, J. Yoon. Biotechnol Bioeng 100 379-386 (2008)

19. M. Gabi, L. Hefermehl, D. Lukic, R. Zahn, J. Voros, D. Eberli. Urological Res 39 81$88(2011)$

20. R. Berthelot. Electrotaxis and Electrical Property Quantification of Pathogenic Bacteria Using Microfluidics and Nanoscale Imaging. Thesis. Master of Science in Biophysics. University of Guelph (2017) 